\title{
„Wychowawca! O jakaż wzniosła musi to być dusza!” Prywatne guwernantki dziewcząt w czasach stanisławowskich
}

\begin{abstract}
A tutor! What a noble soul!” Private girls' governesses during the reign of Stanisław August Poniatowski

In Stanislaw August Poniatowski's time, the upbringing and education of wealthy noblewomen were commonly entrusted to foreign governesses. There was a strong conviction in the Polish-Lithuanian Commonwealth that command of foreign languages was the foundation of proper and careful upbringing of young women. Many parents were not discerning clients when it came to selecting a governess. Oftentimes, foreign origin sufficed. As a result of attaching so much importance to command of foreign languages accompanied by acquiring foreign manners, costumes and customs, young Polish women grew indifferent to their mother tongue, native culture and traditions. There was also a lack of sense of responsibility for the country's future.
\end{abstract}

Keywords: age of Enlightenment, Polish-Lithuanian Commonwealth, education of girls, governess, foreign languages

Sprawa wychowywania dzieci oraz młodzieży była swego rodzaju obsesją tematyczną myślicieli epoki oświecenia, której główny okres w Rzeczypospolitej Obojga Narodów przypada na lata panowania Stanisława Augusta Poniatowskiego (1764-1795)1. Zresztą od wieków wychowywanie młodego pokolenia było uznawane za bardzo ważne zarówno dla jednostki, jak i społeczeństwa. Zdawali sobie z tego sprawę rodzice, którzy w miarę swoich możliwości starali się zapewnić dzieciom jak najlepsze ścieżki edukacji²,

${ }^{1}$ K. Mrozowska, Rozwój koncepcji pedagogicznych w XVIII w., w: Pisma i projekty pedagogiczne doby Komisji Edukacji Narodowej, Wrocław-Warszawa-Kraków-Gdańsk 1973, s. V-LXX.

${ }^{2}$ Por. Ojcowskie synom przestrogi. Instrukcje rodzicielskie (XVI-XVII w.), wstępem i objaśnieniami opatrzyły D. Żołądź-Strzelczyk i M. E. Kowalczyk, Wrocław 2017; Przestrogi i nauki dla dzieci. Instrukcje rodzi- 
ale dostrzegali to również pisarze i publicyści poszczególnych epok ${ }^{3}$. W dobie oświecenia na czoło koncepcji pedagogicznych wysunął się motyw edukacji obywatelskiej i patriotycznej, obejmujący jak najszersze kręgi społeczeństwa ${ }^{4}$. Głos w tej sprawie zabrali m.in.: August Kazimierz Sułkowski (1729-1786), wojewoda kaliski, a następnie poznański, Adam Kazimierz Czartoryski (1734-1823), generał ziem podolskich ${ }^{5}$, Franciszek

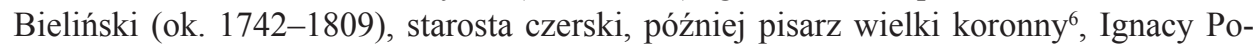
tocki (1750-1809), pisarz wielki litewski, a potem marszałek wielki litewski ${ }^{7}$, ksiądz Grzegorz Piramowicz (1735-1801) ${ }^{8}$ oraz ksiądz Hugo Kołłątaj (1750-1812)9. Byli oni aktywnymi działaczami Komisji Edukacji Narodowej, którzy w swoich rozważaniach na temat reformy nauczania oraz jej modelowego przebiegu nie pominęli kwestii związanej z kształceniem dziewcząt ${ }^{10}$.

Na temat edukacji płci żeńskiej wylano w czasach stanisławowskich morze atramentu. Nie stawiano już pytania „czy”, ale ,jak” należy wychowywać dziewczęta ${ }^{11}$. Jedni uważali, że towarzyszka życia mężczyzny powinna posiadać takie wykształcenie, by być w stanie go zrozumieć, dyskutować z nim, przede wszystkim zaś rozsądnie i odpowiedzialnie wychowywać jego dzieci. Drudzy twierdzili z kolei, że należy maksymalnie

cielskie (XVIII w.), wstępem i objaśnieniami opatrzyły M. E. Kowalczyk, D. Żołądź-Strzelczyk, Wrocław 2017; I. Szybiak, O rodzicielskich zaletach $i$ wadach $w$ oświeceniowej polskiej publicystyce edukacyjnej. w: Nauczanie domowe dzieci polskich od XVIII do XX wieku. Zbiór studiów, red. K. Jakubiak, A. Winiarz, Bydgoszcz 2004, s. 35-45.

${ }^{3}$ Por. D. Żołądź, Ideały edukacyjne doby staropolskiej. Stanowe modele i potrzeby edukacyjne szesnastego i siedemnastego wieku, Warszawa-Poznań 1990; K. Wrońska, Uwagi o recepcji twórczości pedagogicznej Johna Locke'a w Polsce z perspektywy pedagogiki filozoficznej, w: Filozofia wychowania w Europie Środkowej w kontekście uwarunkowań historycznych, społecznych, politycznych i filozoficznych, red. S. Sztobryn, K. Kamiński, M. Wasilewski, Łódź 2015, s. 15-35; eadem, Johna Locke’a koncepcja wychowania - zapowiedź oświeconych przemian w myśli pedagogicznej, https://ruj.uj.edu.pl/xmlui/bitstream/handle/item/22260/wronska_johna_locke\%27a_koncepcja_wychowania.pdf?sequence=1\&isAllowed=y [dostęp: 15.06.2018].

${ }^{4}$ K. Mrozowska, op. cit., s. XIII.; J. Snopek, Oświecenie. Szkic do portretu epoki, Warszawa 1999, s. 61.

${ }^{5}$ H. Waniczkówna, Czartoryski Adam Kazimierz, w: Polski słownik biograficzny, t. 4, Kraków 1938, s. $249-257$.

${ }^{6}$ A. Wolff i W. Budka, Bieliński Franciszek, w: Polski słownik biograficzny, t. 2, Kraków 1936, s. 50-51.

7 Z. Zielińska, Potocki Roman Ignacy Franciszek, w: Polski słownik biograficzny, t. 28, Wrocław-Warszawa-Kraków-Gdańsk-Łódź 1984-1985, s. 1-17.

${ }^{8}$ E. Aleksandrowska, Piramowicz Grzegorz Wincenty, w: Polski słownik biograficzny, t. 26, Wrocław-Warszawa-Kraków-Gdańsk-Łódź 1981, s. 529-536.

9 B. Leśnodorski, Kołłątaj Hugo, w: Polski słownik biograficzny, t. 13, Wrocław-Warszawa-Kraków 1967-1968, s. 335-346.

${ }^{10}$ M. Mitera-Dobrowolska, Zainteresowanie Komisji Edukacji Narodowej sprawa wychowania dziewcząt, w: Ł. Kurdybacha, M. Mitera-Dobrowolska, Komisja Edukacji Narodowej, Warszawa 1973, s. 173-189; W. Stetkiewiczówna, System wychowania kobiet wedlug KEN, „Przegląd Pedagogiczny” 1924, z. IV, s. 222-236.

11 Por. D. Żołądź-Strzelczyk, „Jako rządzić mają rodzice córki swe”. Poglądy na wychowanie kobiet w XVI-XVIII w., w: Rola i miejsce kobiet w edukacji i kulturze polskiej, red. W. Jamrożek i D. Żołądź-Strzelczyk, t. 1, Poznań 1998, s. 53-63; E. Podgórska, Sprawa wychowania kobiet w znaczniejszych czasopismach polskich drugiej połowy XVIII wieku, „Rozprawy z Dziejów Oświaty” 1961, t. IV, s. 19-33. 
zniwelować różnice w edukacji obu płci, zapewniając kobietom należne miejsce w społeczeństwie $^{12}$. W opinii Franciszka Bielińskiego rola kobiety była równie doniosła jak mężczyzny, a złe jej wychowanie przynosiło dużą szkodę społeczeństwu i ojczyźnie. Zgodnie z tym postulował: Ażeby dobre obyczaje kwitnęty w kraju, potrzeba starać się zaszczepić je w sercach młodych panien i edukacja ich powinna się do męskiej edukacji stosować, jeżeli chcemy, aby skuteczna nasza byta edukacja13. Wtórował mu Hugo Kołłątaj: Zgoła wysilajmy, jak chcemy, dowcip na ulepszenie naszych obyczajów, zawsze będziemy tym, czym będzie druga nasza połowa, czym będa kobiety, z którymi żyć, z którymi obowiązi społeczne dzielić przeznaczyła nas Opatrzność ${ }^{14}$.

Na temat wychowania płci żeńskiej wypowiadali się nie tylko mężczyźni, ale coraz śmielej same kobiety ${ }^{15}$. Konstancja z Czartoryskich (1742-1797), żona Klemensa Jerzego Zamoyskiego (1738-1767), VIII ordynata, a po jego śmierci Andrzeja Zamoyskiego (1717-1792), X ordynata, pisała: Kobieta nie powinna starać się być naukowcem, politykiem, ani też mieć zbytnio wygórowanego mniemania o sobie, bo ja to [tylko] ośmieszy. Powinna natomiast wiedzieć tyle, żeby wszystko rozumieć, nie być niczym znudzona, umieć poczynić obserwację na dany temat i umieć czerpać radość z wiedzy innych ${ }^{16}$. Tymczasem w roku 1779 na łamach „Monitora”, popularnego w czasach stanisławowskich czasopisma, niejaka Karolina skarżyła się, że edukacja dziewcząt w zakresie prawa, historii, geografii jest znikoma, a braki i niedostatki wychowania umysłowego skutkują odsunięciem kobiet od życia społecznego. O domaganiu się wojażu - pisała - ani ust otworzyć nie śmiem znająca $w$ kraju $i w$ domu swoja niedolę ${ }^{17}$. W jej opinii kobiety były pokrzywdzone w porównaniu z mężczyznami, którzy otrzymywali staranne wychowanie domowe lub szkolne, uzupełnione często wielomiesięczną podróżą edukacyjną po Europie. Dziewczętom każą natomiast $w$ domu siedzieć, książki tylko nabożeństwu stużace pilnować, uczyć się po francusku, po niemiecku, i to z madame, a rzadko kiedy z metrem, nie pozwalajac czytać pism drukowanych autorów dowcipnych ${ }^{18}$. Kim była madame, o której wspominała Karolina? W czasach staropolskich tym grzecznościowym

\footnotetext{
12 Por. M. Bogucka, Białogłowa $w$ dawnej Polsce. Kobieta w społeczeństwie polskim XVI-XVIII wieku na tle porównawczym, Warszawa 1998, s. 145-147, 161-162; D. Godineau, Kobieta, w: Człowiek Oświecenia, red. M. Vovelle, Warszawa 2001, s. 416.

${ }^{13}$ F. Bieliński, Sposób edukacji w XV listach opisany, które do Komisji Edukacji Narodowej od bezimiennego autora byty przesylane R. P. 1775, w: Pisma i projekty pedagogiczne doby Komisji Edukacji Narodowej..., s. 118.

${ }^{14}$ H. Kołłątaj, Wybór pism naukowych, oprac. K. Opałek, Warszawa 1953, s. 195-197.

15 E. Podgórska, op. cit., s. 26.

${ }^{16}$ Archiwum Główne Akt Dawnych w Warszawie, Archiwum Zamoyskich, sygn. 76. Akta Konstancji z Czartoryskich Zamoyskiej, s. 45. Przekład z j. franc. A. Pikor-Półtorak.

17 „Monitor” 1779, nr LIX, s. 435.

18 Ibidem.
} 
zwrotem określano zwykle guwernantkę, czyli domową nauczycielkę i wychowawczynię będącą najczęściej Francuzką ${ }^{19}$.

Zamożni szlacheccy rodzice powszechnie powierzali naukę i wychowanie córek guwernantkom. Dziewczęta dostawały swoje opiekunki i mentorki bardzo wcześnie. Inflantczyk Fryderyk Schulz, który bawił w Rzeczypospolitej Obojga Narodów w latach 1791-1793, stwierdził wprost: Dziewczęta, jak tylko mówić zaczynaja, dostaja guwernantki. Te rzadko kiedy nie sa Francuzkami ${ }^{20}$. Natalia z Bispingów Kicka (1801-1888) wspominając ciotkę Izabelę Sobolewską (1776-1858), córkę Jerzego Grabowskiego (zm. 1789), generała lejtanta wojsk koronnych i Elżbiety z Szydłowskich (1748-1810), długoletniej metresy króla Stanisława Augusta Poniatowskiego, zanotowała na kartach pamiętnika: Wychowana jak wszystkie nasze magnatki ówczesne przez nauczycielkę Francuzkę $e^{21}$. Pod czujnym okiem guwernantki, niejakiej panny Roux, uczyły się języka francuskiego i nabierały manier Józefa (1786-1813 lub 1814) i Henrieta (1794 - po 1860) Działyńskie, córki generała Ignacego Józefa (1754-1797) i Szczęsnej z Woroniczów. Henrieta w swym pamiętniku odnotowała, że powszechnie była chwalona za doskonały akcent francuski. Ten język - wspominała - posiadłam od kolebki, gdyż panna Roux, będaca przy mojej siostrze, ciagle do mnie tym językiem mówiła, za jej rada dano mi imię $e^{22}$. W wieku pięciu lat dostała francuską guwernantkę Zofia z Czartoryskich Zamoyska (1778-1837), najmłodsza córka generała ziem podolskich Adama Kazimierza Czartoryskiego i Izabeli z Flemingów (1746-1835). Była nią panna Petit - dobra i szanowna, ale bardzo stara i chorowita ${ }^{23}$. Wychowała ona najpierw Izabelę Czartoryską, a później jej dwie starsze córki: tragicznie zmarłą Teresę (1765-1780)24 oraz Marię (1768-1854), która w 1784 r. poślubiła księcia Ludwika Wirtemberskiego (1756-1817) ${ }^{25}$. Zofia, która została powierzona wyłącznej opiece sędziwej panny Petit, tak o niej napisała po latach: Była rozumna, miła $i$ z pewna oryginalnościa [...], ale często drażliwa i cierpiaca nie mogła baczniej zwracać uwagi na moja edukację, toteż brakowało nadzoru $w$ moich naukach, nad zdrowiem, a nawet pokierowaniem zasadami - a niedostatek ten później silnie odczułam. Trzeba przyznać, że byłam nadzwyczaj

19 S. B. Linde, Stownik języka polskiego, t. 1, cz. 2, Warszawa 1808, s. 803.

${ }^{20}$ F. Schulz, Podróże Inflantczyka z Rygi do Warszawy i po Polsce w latach 1791-1793, w: Polska stanisławowska w oczach cudzoziemców, oprac. W. Zawadzki, t. II, Warszawa 1963, s. 591.

${ }^{21}$ N. Kicka, Pamiętniki, wstęp i przypisy J. Dutkiewicz, tekst oprac. T. Szafrański, Warszawa 1972, s. 96.

${ }^{22}$ H. z Działyńskich Błędowska, Pamiątka przeszłości. Wspomnienia z lat 1794-1832, oprac. K. Kostenicz i Z. Makowiecka, Warszawa 1960, s. 35.

${ }^{23}$ L. Dębicki, Puławy (1762-1830). Monografia z życia towarzyskiego, politycznego i literackiego na podstawie archiwum ks. Czartoryskich w Krakowie, t. 4, Lwów 1888, s. 285.

${ }^{24}$ M.E. Kowalczyk, Pamięć o tragicznie zmarłej księżniczce Teresie Czartoryskiej (1765-1780), w: Nie wszystek umrę. Pamięć o zmartych w kulturze staropolskiej, red. A. Jankowski, A. Klonder, Bydgoszcz 2015, s. 232-243.

${ }^{25}$ L. Dębicki, Puławy (1762-1830)..., t. 4, s. 285-286. 
zaniedbanq ${ }^{26}$. Więcej szczęścia miała Wirydianna z Radolińskich (1761-1826), primo voto Kwilecka, secundo voto Fiszerowa. Gdy skończyła pięć lat rodzice - Katarzyna z Raczyńskich (1744-1792) i Józef Radoliński (1730-1781), podkomorzy wschowski, zatrudnili do jej wychowania cudzoziemską guwernantkę, o której Fiszerowa zanotowała na kartach pamiętnika: Niezwyklym trafem wybór jej padt na osobę wyksztatconą. Wypadek to byt niezmiernie rzadki w owym czasie, kiedy dziewczyny ignorantki podejmowaty się uczyć tego, czego same nie umiały. Wierzono im na stowo tym bardziej, że mato kto byt w stanie prace ich ocenić ${ }^{27}$.

Oczywiście zdarzali się rodzice, którzy zanim podjęli decyzję o sprowadzeniu guwernantki do domu, zasięgali wiadomości na temat jej kompetencji w kręgu krewnych, powinowatych, przyjaciół i znajomych. Tak uczyniła Ludwika z Rzewuskich (1744-1816), żona Jana Mikołaja Chodkiewicza (1738-1781), starosty żmudzkiego. W 1777 r. postanowiła zatrudnić dla córek Rozalii (1768-1793) i Elżbiety (1771-1804) nową francuską nauczycielkę. Zarekomendowano jej niejaką panią de Savoie. Starościna żmudzka bez wahania obiecała jej posadę na dworze w Czarnobylu ${ }^{28}$. Gdy jednak dowiedziała się, że nic więcej nie umi jak tylko po francusku mówić i czytać, postanowiła odmówić jej służbę, twierdząc: Byłoby rzecza niepotrzebna, gdybym ja sprowadziła na miejsce tej, która tyle umi wiele ${ }^{29}$. Ludwika Chodkiewiczowa obawiała się, że urażona guwernantka będzie ją obgadywała za niedotrzymanie obietnicy. Poprosiła więc znajomych, aby oznajmili jej, że postanowiła ulokować dziewczynki u pewnej Francuzki na pensyi, dlatego jej ani $\dot{z} a d n e j$ nie potrzebuje $e^{30}$. Było to postępowanie obliczone na wprowadzenie de Savoie w błąd. Starościna żmudzka przyznała bowiem wprost: Ja nie myślę oddawać dzieci na pensja, tylko to piszę dla uspokojenia madamy, dlatego żeby ona była pewna, że u mnie miejsca mieć nie będzie $e^{31}$. Dotychczasowa guwernantka zachowała posadę na czarnobylskim dworze ku radości dziewczynek. Była ona bowiem właścicielką szpaka, któren więcej jak 40 stów po francusku umi ${ }^{32}$. Ptak wzbudzał powszechny zachwyt. Pewnego dnia ukradł go z zamiarem sprzedania innej osobie kuchmistrz Chodkiewiczów. Czego gdyśmy doszli, mój mąż zaraz z jego stancyi szpaka odebrat, a jemu wyjechać kazal - relacjonowała znajomemu w liście z 27 lipca 1777 r. z Czarnobyla starościna żmudzka ${ }^{33}$.

\footnotetext{
${ }^{26}$ Kufer Kasyldy, czyli wspomnienia z lat dziewczęcych. Wyboru z pamiętników XVIII-XIX w. dokonały D. Stępniewska i B. Walczyna, Warszawa 1974, s. 18.

${ }_{27}$ W. Fiszerowa, Dzieje moje własne i osób postronnych. Wiąanka spraw poważnych, ciekawych i błahych, oprac. E. Raczyński, Londyn 1975, s. 31.

${ }_{28}$ Archiwum Narodowe w Krakowie, Oddział I na Wawelu, AMCh, sygn. 479, Kopiariusz listów Ludwiki Chodkiewiczowej oraz listy do różnych osób, 1768-1807, s. 159.

29 Ibidem, s. 381.

30 Ibidem, s. 381.

31 Ibidem.

32 Ibidem, s. 161

33 Ibidem, s. 159
} 
Pomimo zwyczaju przekazywania nauczycieli z rekomendacjami z dworu do dworu, poszukiwano też guwernerów za pośrednictwem prasy ${ }^{34}$. Nie wszyscy rodzice mieli bowiem wśród swojej rodziny lub znajomych osoby, które mogły im polecić odpowiednią nauczycielkę. Zatem wystawiali ogłoszenia w gazetach, precyzując swoje wymagania: Pewne Państwo o mile 22 od Warszawy mieszkajace, żąda mieć do edukacji dzieci madamę wieku średniego, umiejąca po francusku i po niemiecku, a przynajmniej po francu$s k u^{35}$.

Nie ulega wątpliwości, że rodzice zwracali w jakimś stopniu uwagę, kogo angażują do wychowania córek, tym bardziej, że edukacja w Rzeczypospolitej Obojga Narodów wcale nie należała do tanich. Fryderyk Schulz pisał: Gdy we Włoszech i Niemczech nic taniej nie przychodzi nad wychowanie i nadzór dzieci, w Polsce jest to najkosztowniejszym. [...] Jeśli się wymaga manier, ogłady światowej, języków żyjacych, tych tu nikt nie posiada; potrzeba guwernerów sprowadzać z Niemiec, z Francji, z Włoch kosztem wielkim i opłacać ich drogo, jak wymaga rzadkość tych talentów w Polsce i ofiara, która czynia opuszczając kraj, rodzinę i przyjaciót, a przenoszac się na obczyznę. Tak się zwykle dzieje z tymi nauczycielami, których przedniejsze rodziny dla wykształcenia umystowego i obyczajowego swych dzieci, tak samo z metrami jazdy, tańca, rysunków i muzyki. Wszyscy prawie sa cudzoziemcami i musza oni za przeniesienie się żąać wynagrodzenia, które by im na powrót do kraju postugiwało, i każa się płacić drogo ${ }^{36}$.

W epoce oświecenia podnosiło się w Europie wiele głosów w sprawie zatrudniania obcych osób w celu wychowywania dzieci. Przeciw oddawaniu najmłodszych pod opiekę nieznajomych występował sławny genewski pedagog i pisarz tworzący w języku francuskim Jan Jakub Rousseau (1712-1778). Jego dzieła literackie, w szczególności Julia, czyli Nowa Heloiza (1760), Emil, czyli o wychowaniu (1762) i Wyznania (1788) wywarły ogromny wpływ na szerokie rzesze czytelników ${ }^{37}$. Mistrz teorii wychowania pisał w Emilu...: Wychowawca! O jakaż wzniosła musi to być dusza! Zaprawdę, ażeby uksztattować człowieka, trzeba być samemu albo rodzicem, albo więcej niż człowiekiem. Takie to czynności powierzacie spokojnie obcym ludziom ${ }^{38}$. Rousseau z jednej strony protestował przeciwko praktykom oddawania dzieci pod opiekę nauczycieli, z drugiej zachęcał ojców i matki, aby sami wychowywali swoje potomstwo.

Tymczasem w Rzeczypospolitej Obojga Narodów publicyści i pedagodzy ostro sprzeciwiali się wychowywaniu młodego pokolenia zamożnej szlachty nie tyle przez guwernerów, co obcokrajowców. Stawiano bowiem na edukację w duchu patriotycznym. Teo-

34 Z. Chyra, Nauczyciele prywatni (1764-1807), w: Spoleczeństwo polskie XVIII i XIX wieku, red. J. Leskiewiczowa, t. VI, Państwowe Wydawnictwa Naukowe, Warszawa 1974, s. 25.

35 „Gazeta Warszawska”, 1782, nr 5, supl.

36 F. Schulz, op. cit., s. 552.

${ }^{37}$ M. Ludwisiak, Postać Jana Jakuba Rousseau i jego wplyw na współczesnych, „Acta Universitatis Lodziensis. Folia Historrica" t. 81, 2007, s. 87-108.

38 J. J. Rousseau, Emil czyli o wychowaniu, wstęp i oprac. J. Legowicz, t. I, Wrocław 1995, s. 27. 
retycy wychowania podkreślali rolę bardzo dobrej znajomości języka polskiego w mowie i piśmie oraz historii narodowej. Zgodnie z tym chciano, aby młodzi ludzie byli kształceni na świadomych obywateli własnego kraju, zorientowanych w sprawach publicznych. Najbardziej popularną pracą dotyczącą wychowania i edukacji kobiet w czasach stanisławowskich stały się Listy Imci Pana Doświadczyńskiego napisane w roku 1782 przez Adama Kazimierza Czartoryskiego, które miały być odpowiedzią na prośbę jego przyjaciela o porady dotyczące wychowania córek. Oprócz szeregu różnych wskazówek dotyczących wychowania dziewcząt, autor ostrzegał przed przyjmowaniem do domów cudzoziemek, zauważając, że łatwo i małym kosztem dostać już teraz można ze szkół krajowych osoby zdolne do uczenia ${ }^{39}$. W tym samym duchu pisał pijar Antoni Maksymilian Prokopowicz (1738-1807), kaznodzieja pedagog, historyk oraz tłumacz ${ }^{40}$. Kładąc nacisk na naukę języka polskiego oraz wychowanie w duchu patriotycznym, w swoim słynnym dziele pt. Sposób nowy, najłatwiejszy pisania i czytania razem dla panienek z przypisami dla nauczycielek apelował do matek i ojców: Czas by już, żeby radzac się rozumu, nie przesadu, uznali rodzice i nawet doświadczeniem byli przekonani, że lepsza rzecz Polkę, niżeli jakowa Francuzkę obrać do córki za nauczycielkę. [...] Gdzież te sa nauczycielki Polki? Znajdziecie ich dosyć, byleście chcieli, a przynajmniej tyle od was rodziców miały Polki względów, luboć więcej warte być by powinne, ile owe madamy francuskie maja, albo niemieckie sfrancuziałe ${ }^{41}$.

Niestety w żadnym znanym dotychczas dzienniku i pamiętniku z czasów stanisławowskich nie została odnotowana guwernantka-Polka wychowująca zamożne szlachcianki. Dziewczęta powszechnie posiadały domowe nauczycielki obcego pochodzenia. Pomimo nacisku, jaki starano się położyć na dobre opanowanie ojczystego języka, panowało w Rzeczypospolitej Obojga Narodów silne przekonanie, że znajomość cudzoziemskich języków u kobiet była podstawą dobrego i starannego wychowania. Przebywający nad Wisłą w latach siedemdziesiątych XVIII w. Lotaryńczyk Hubert Vautrin (1742-1822) zauważył: Za bardzo zaniedbane uważa się wychowanie panny, które nie umie mówić przynajmniej po francusku. Dotyczy to zreszta jedynie zamożnych domów, toteż o pozostałych dziewczętach nie mówi się nigdy, że otrzymały wychowanie ${ }^{42}$. W powszechnej opinii szlachty polskiej dobrą znajomość obcych języków gwarantowały nauczycielki pochodzenia cudzoziemskiego.

${ }^{39}$ A. Czartoryski, Drugi list Imć Pana Doświadczyńskiego do przyjaciela swego względem edukacyi córek, w: S. Tync, Komisja Edukacji Narodowej: (pisma Komisji i o Komisji): wybór źródet, Wrocław 1954, s. 298.

40 D. Żołądź-Strzelczyk, Antoniego Maksymiliana Prokopowicza Sposób nowy najłatwiejszy pisania i czytania razem dla panienek z przypisami dla nauczycielek - pierwszy polski podręcznik edukacji elementarnej dla dziewcząt, „Kwartalnik Historii Kultury Materialnej” 2014, R. 62, nr 4, s. 553-565.

${ }^{41}$ A. M. Prokopowicz, Sposób nowy, najłatwiejszy, pisania i czytania razem dla panienek, z przypisami dla nauczycielek, Kraków 1790, Przedmowa do rodziców.

${ }^{42}$ H. Vautrin, Obserwator w Polsce, w: Polska stanisławowska w oczach cudzoziemców, oprac. W. Zawadzki, t. I, Warszawa 1963, s. 796. 
Tymczasem polscy teoretycy wychowania na problemy z kompetentnymi rodzimymi guwernantkami przychodzili z pomocą. Jeżeli zaś nie wystarcza Polek do edukacyi zdolnych, więc wy, o zacne damy, ozdoby ojczyzny, Spartanki narodu naszego [...] wstawcie się wziętościa wasza, która wiele dokazać zdołacie ${ }^{43}$. Proponowano nie tylko szkolenie szlachcianek na nauczycielki i stwarzanie dla nich stosownych szkół ${ }^{44}$, lecz zachęcano również same matki do dokształcania się, aby mogły odpowiedzialnie edukować córki. Adam Kazimierz Czartoryski sugerował kobietom lekturę dzieł konkretnych znakomitych polskich pedagogów: Karola Wyrwicza (1717-1793) ${ }^{45}$, Teodora Wagi (1739-1801) ${ }^{46}$, Antoniego Popławskiego (1739-1799) ${ }^{47}$. Z tymi - pisał Czartoryski - niech się matki obeznają, mniej będa miaty próżnych godzin ${ }^{48}$. Nie zapominajmy też, że wśród Polek w tym czasie bardzo popularne były pisma samego Jana Jakuba Rousseau. Wirydianna Fiszerowa wprost przyznała w pamiętniku, że lektura dzieł genewskiego pedagoga w młodości wzbudziła w niej zapalczywy $i$ goracy afekt do ich autora. Śniłam tylko o tym, by wyjść za mąz po to, by go jak najrychlej odwiedzić i skorzystać z jego nauk ${ }^{49}$. Zagorzałą russoistką była Izabela z Czartoryskich Lubomirska (1736-1816) ${ }^{50}$ oraz jej bratowa Izabela z Flemingów Czartoryska ${ }^{51}$, która miała okazję poznać pisarza osobiście, kiedy w 1761 r. przebywała z mężem w Paryżu ${ }^{52}$. Księżna marszałkowa Lubomirska pod wpływem lektury dzieł Rousseau nadała najmłodszej swojej córce, urodzonej we Francji w 1767 r., imię Julia, a ukochanego wychowanka Henryka Lubomirskiego (1777-1850)

${ }^{43}$ A. M. Prokopowicz, op. cit., Przedmowa do rodziców.

${ }^{44}$ Ibidem.

${ }^{45}$ K. Wyrwicz, Geografia czasów teraźniejszych, albo opisanie naturalne i polityczne królestw, państw, stanów wszelkich, ich rządu, rzemiost, handlu, przemystu, przymiotów, obyczajów etc. ku pożytkowi narodowej młodzi wydana, t. I, Warszawa 1768; idem, Geografia powszechna czasów teraźniejszych albo opisanie krótkie całego świata, ich położenia, granic, płodu ziemnego, skłonności obywatelów, handlu, obyczajów etc. etc. Z najświeższych wiadomości, krajopisarzów i wędrowników zebrana ku pożytkowi młodzi narodowej na szkoły publiczne wydana, Warszawa 1770. Por. K. Augustowska, Karol Wyrwicz, w: Dziewięć wieków geografii polskiej. Wybitni geografowie polscy, pod red. B. Olszewicza, Warszawa 1967, s. 117-137.

${ }^{46}$ T. Waga, Historia książąt i królów polskich krótko zebrana z niektórymi uwagami nad dziełami narodu dla oświecenia młodzi narodowej przez...do druku podana, Warszawa 1770, Por. T. Słowikowski, Pijarskie podręczniki do nauczania historii w Polsce w XVIII wieku, „Nasza Przeszłość” t. 54, 1980, s. 181-299.

${ }^{47}$ A. Popławski, Nauka o prawie przyrodzonym krótko i jaśnie zebrana, [b.m.w.] 1771, Por. E. Aleksandrowska, Popławski Antoni, w: Dawni pisarze polscy od początku piśmiennictwa do Młodej Polski, red. R. Loth, Warszawa 2002, s. 272-273; M. Chamcówna, Popławski Jacek, w: Polski słownik biograficzny, t. 26, Wrocław 1983, s. 602-603.

48 A. K. Czartoryski, op. cit., s. 298.

49 W. Fiszerowa, op. cit., s. 73.

${ }^{50}$ B. Majewska-Maszkowska, Mecenat artystyczny Izabelli z Czartoryskiej Lubomirskiej (1736-1816), Wrocław 1976, s. 177-179.

${ }^{51}$ A. Aleksandrowicz, Izabela Czartoryska. Polskość i europejskość, Lublin 1998, s. 139-152.

${ }^{52}$ L. Dębicki, Puławy (1762-1830). Monografia z życia towarzyskiego, politycznego i literackiego na podstawie archiwum ks. Czartoryskich w Krakowie, t. 1, Lwów 1887, s. 95-96. 
nazywała „swoim Emilem”53. Za radami Rousseau starała się wychowywać siedmioro dzieci Konstancja z Czartoryskich Zamoyska ${ }^{54}$. Także Szczęsna z Woroniczów Działyńska, gdy w końcu odesłała nie pasującą jej guwernantkę, zaczęła córkę edukować à la Rousseau. Jak wspominała Henrieta z Działyńskich Błędowska była wszelka wolność uczyć się lub nie $e^{55}$. Jednak są to pojedyncze przykłady. Z reguły dziewczynki po mamkach i piastunkach, które były przy nich od urodzenia, w dalszej kolejności dostawały guwernantki.

Matki mało się wówczas zajmowały dziećmi, które mieszkaty daleko, całkowicie powierzone bonom i guwernantkom - wspominała czasy stanisławowskie Zofia z Czartoryskich Zamoyska ${ }^{56}$. Panie z kręgów zamożnej szlachty rzadko oglądały swoje córki. Co jakiś czas kontrolowały tylko figurę oraz toaletę dziewczynek, przy okazji ofiarując im różne klejnociki ${ }^{57}$. Często opieka matki sprowadzała się do przeprowadzania inspekcji czystości dziecięcych ubrań i rąk przed obiadem, przygotowania lekarstw $w$ razie choroby, sprawdzania okazjonalnie $w$ sypialniach rano "co tam pod kołdra» $i$ wymierzania $k_{a r y}{ }^{58}$. Nowatorskie podejście do dzieci miała Izabela z Flemingów Czartoryska. Zofia Zamoyska z dumą pisała o matce: Była pierwsza w Polsce, co się otaczała dziećmi, widziano ja często przechadzająca się z niemi, $i$ w ich gronie spędzajaca czesść dnia. Przykład ten był naśladowany najpierw przez modę, później z prawdziwego uczucia ${ }^{59}$. Niestety, o ile starszym dzieciom księżna poświęcała dużo uwagi i czasu, o tyle najmłodszą córkę Zofię widywała sporadycznie. Wynikało to z jej licznych podróży oraz zaangażowania w patriotyczną działalność polityczną. Moja matka - pisała Zofia - miała wielkie powody całkowitego zaufania w pannie Petit, która ja sama wychowała i tak wybornie pokierowata wychowaniem starszej mej siostry Marii. Guwernantki w owych czasach miewaty władze nieograniczona. Panna Petit była kochana i szanowana przez moich rodziców, którzy byli przekonani, że wszystko pod jej kierunkiem musiało iść wybornie ${ }^{60}$.

Wielu rodziców bez wahania przelewało na guwernantki swoje prawa i obowiązki, jakie mieli wobec córek. Skoro domowe nauczycielki spędzały z dziewczynkami mnóstwo czasu, rodziła się między nimi silna więź emocjonalna. Wielkie przywiązanie do swojej opiekunki opisała Apolonia Helena Massalska (1763-1815), córka podskarbiego nadwornego litewskiego Józefa Adriana (ok. 1726-1765) i Antoniny z Radziwiłłów

${ }^{53}$ B. Majewska-Maszkowska, op. cit., s. 177.

54 Archiwum Główne Akt Dawnych w Warszawie, Archiwum Zamoyskich, sygn. 76. Akta Konstancji z Czartoryskich Zamoyskiej, s. 29-63.

${ }^{55}$ H. z Działyńskich Błędowska, op. cit., s. 37

${ }^{56}$ L. Dębicki, Puławy (1762-1830)..., t. 4, s. 289.

57 A. Berdecka, I. Turnau, Życie codzienne w Warszawie okresu Oświecenia, Warszawa 1969, s. 129.

58 K. Bartnicka, Dziecko w świetle pamiętników i powieści polskiego Oświecenia, „Rozprawy z Dziejów Oświaty" nr 35, 1992, s. 61.

59 Kufer Kasyldy, czyli wspomnienia z lat dziewczęcych..., s. 21.

${ }^{60}$ Ibidem. 
(1730-1764). Rodzice bardzo wcześnie ją osierocili. Kuratelę nad małoletnią przejął Ignacy Massalski (1726-1794), biskup wileński i działacz polityczny. Jesienią $1771 \mathrm{r}$. stryj wywiózł ją do Paryża i umieścił w klasztornym pensjonacie Abbaye-aux-Bois. Podskarbianka była bardzo delikatnego zdrowia i częste niedomagania oraz choroby, z których tygodniami nie mogła się wykaraskać, spowodowały, że otrzymała własny apartament oraz guwernantkę pannę Bathilde Toutevoix, która pokochała ją do szaleństwa i czule się o nią troszczyła. W zamian w dniu, w którym Apolonia Helena Massalska wyszła za mąż za księcia Karola Antoniego de Ligne (1759-1792), panna Toutevoix otrzymała kwit na 600 liwrów dożywotniego dochodu ${ }^{61}$. Nawet Zofia z Czartoryskich Zamoyskich, która skarżyła się na zaniedbane wychowanie i edukację, wspominając sędziwą pannę Petit, wyznała: Była dobra, kochałam ja [...], miałam upodobanie $w$ jej towarzystwie ${ }^{62}$.

Obecność w domu magnackim obcojęzycznej guwernantki nadawała prestiżu, była wyznacznikiem panującej mody i trendów w sposobie wychowywania. Edukacja prowadzona przez cudzoziemki miała swoje dobre i złe strony. Do tych pierwszych należy zaliczyć upowszechnienie w Polsce gry scenicznej i rozwój zainteresowania życiem literackim i kulturalnym. Wiele guwernantek uczyło na bardzo dobrym poziomie muzyki i śpiewu. Im też Polki zawdzięczały doskonałą znajomość języka Woltera czy Goethego. Już w 1764 r. francuski pisarz i podróżnik Jacques-Henri Bernardin de Saint-Pierre (1737-1814), zauważył, że w Rzeczypospolitej Obojga Narodów większość [szlachcianek] włada językiem niemieckim i francuskim z doskonałościa rzadko spotykana nawet wśród mieszkańców tych krajów, [...], a w wolnych chwilach zajmuja się literatura, mu$z y k a$, sztukami pięknymi ${ }^{63}$. Tak oto dzięki francuskiej guwernantce staranną edukację językową otrzymały córki Tekli Despot-Zenowicz (zm. ok. 1818) i Józefa Sosnowskiego (zm. 1783), pisarza polnego litewskiego, potem hetmana polnego litewskiego, a następnie wojewody połockiego: Ludwika (ok. 1750-1836) i Katarzyna (ok. 1748-1832). W wieku kilkunastu lat siostry już tak dobrze znały język francuski, że zajęły się tłumaczeniem dzieła szwajcarskiego agronoma Hansa Kaspara Hirzela. Z ogromnym uznaniem i podziwem o ich przekładzie wyraził się profesor Ignacy Nagurczewski (1725-1811), poeta, historyk literatury, tłumacz dzieł Cycerona, Demostenesa, Homera i wykładowca w Szkole Rycerskiej, a także uczestnik słynnych „obiadów czwartkowych” Stanisława Augusta Poniatowskiego. Książka Sokrates wieśniak albo opisanie życia gospodarskiego i cnotliwego filozofa rola bawiacego się. Przez JJ. WW. Jmć Panny Katarzynę i Ludwikę Sosnowskie pisarzówny polne W. X. Litewskiego z francuskiego na polskie przettumaczo-

\footnotetext{
${ }^{61}$ M. E. Kowalczyk, Wstęp, w: Apolonia Helena Massalska. Pamiętnik pensjonarki. Zapiski z czasów edukacji w Paryżu (1771-1779), wstęp i oprac. M. E. Kowalczyk, przekład z j. franc. A Pikor-Półtorak, Kraków 2012, s. 20.

${ }^{62}$ L. Dębicki, Puławy (1762-1830)..., t. 4, s. 285.

${ }^{63}$ J. H. Bernardin de Saint-Pierre, op. cit., t. I, s. 207.
} 
ny ukazała się w Warszawie w 1770 r. Publikacja przyniosła Ludwice i Katarzynie sławę sawantek $^{64}$.

Guwernantki - oprócz czysto dydaktycznych obowiązków - pełniły też rolę wiernych towarzyszek dorastających dziewcząt. Były łączniczkami między nimi i rodzicami, a często nie rozumiejąc języka, gwarantowały zachowanie dyskrecji w problemach wychowawczych ${ }^{65}$. Skądinąd, głosy przeciw prywatnym zagranicznym nauczycielkom podnosiły się nie bez powodu. Hubert Vautrin wspominał, że guwernantka, której obce sa miejscowe zwyczaje i język, bądź nie dostrzega niebezpieczeństwa kryjącego się za słowami i złym przykładem, badź też zbyt słabym rozporzadza autorytetem by mu zapobiec ${ }^{66}$. Pisał także, że powierzanie dzieci cudzoziemcom nie zapewnia im $w$ większości wypadków lepszego pokierowania rozwojem umystu i serca [...]. Guwernerzy, nauczyciele to często złoczyńcy, których niecne postępki wygnały z ojczyzny ${ }^{67}$. Tego samego zdania był Antoni Maksymilian Prokopowicz, który w ostrych słowach pisał o nauczycielkach cudzoziemskiego pochodzenia: Madamy te, czy mademoiselle są istne awanturnice, które swój kraj, dopuściwszy się niechwalebnego jakiego uczynku, opuszczając, albo z niego uciekając, szukają w Polszcze gnieżḋenia się. [...] Ile kłopotu, ulegania, subiekcyi musiano użý z temi zbiegłemi madamami, na polskim chlebie tuczacemi się, z temi ostawiajacemi Polske guwernantkami ${ }^{68}$.

Dużą grupę cudzoziemskich nauczycielek można było spotkać w Polsce po roku 1789. Wybuch rewolucji francuskiej zmusił licznych przedstawicieli francuskiej noblesse do emigracji. Anna Tyszkiewiczówna (1779-1867), primo voto Potocka, secundo voto Dunin-Wąsowiczowa, córka Konstancji z Poniatowskich (1759-1830) i Ludwika Tyszkiewicza (1748-1808), marszałka wielkiego litewskiego, odnotowała na kartach pamiętnika, że przez wychowanie pośród Francuzów instynktownie przyswajała sobie „ducha ich języka" oraz z wielkim zamiłowaniem czytała ich literaturęé. Kulturą dworu francuskiego była przesiąknięta Izabela Sobolewska, ciotka Natalii Kickiej, która na kartach pamiętnika zanotowała: W oczach pań wykształconych pod wpływem francuskiej emigracji, tak gościnnie u nas przyjmowanej, godzien byt szczerego politowania każden, kto tylko nie czut potrzebę dla Burbonów nieść życie w ofierze ${ }^{70}$.

${ }^{64}$ M. E. Kowalczyk, Wstęp, w: K. z Sosnowskich Platerowa, Moja podróż do Włoch. Dziennik z lat 1785-1786, Łomianki 2013, s. 9-12.

${ }^{65}$ M. G. Zieliński, Rola cudzoziemek w procesie edukacji młodzieży w okresie stanisławowskim (1764-1795), w: Rola i miejsce kobiet w edukacja i kulturze polskiej, t. 1, red. W. Jamrożek i D. Żołądź-Strzelczyk, Poznań 1998, s. 104-107.

${ }^{66}$ H. Vautrin, op. cit., s. 796.

${ }^{67}$ Ibidem, s. 792.

68 A. M. Prokopowicz, op. cit.

69 A. z Tyszkiewiczów Potocka-Wąsowiczowa, Wspomnienia naocznego świadka, Warszawa 2010, s. 23.

${ }^{70}$ N. Kicka, op. cit., s. 96-97. 
Dziewczęta prawie bez przerwy przebywając z cudzoziemskimi guwernantkami, nie tylko zdobywały doskonałe wykształcenie językowe, ale też przejmowały od nich różne inne cechy - sposób poruszania się, gestykulowania, mówienia, a nawet myślenia ${ }^{71}$. Jak zauważył Fryderyk Schulz, Francuzki wychowywały na modłę francuską, Niemki na niemiecką ${ }^{72}$. Była to normalna i dość częsta praktyka. Magnaccy rodzice mając do wyboru oddanie córek na pensję, albo edukację domową, wybierali zwykle to drugie. Tak oto pisarz wielki litewski Ignacy Potocki (1750-1809) po śmierci żony Elżbiety z Lubomirskich (1755-1783) wolał powierzyć opiekę nad córką Krystyną (1773-1800) niemieckiej guwernantce, niż oddać jedynaczkę do klasztoru ${ }^{73}$. Panna Regina Hoffmann była wieloletnią prywatną opiekunką i nauczycielką pisarzówny wielkiej litewskiej74.

Kiedy guwernantka nie umiała już przekazać odpowiedniej wiedzy i umiejętności młodej arystokratce, rodzice zatrudniali dodatkowych nauczycieli, tak zwanych metrów. Dziewczęta uczyły się od nich najczęściej muzyki, tańca, rysunku, czyli tzw. talentów przyjemnych, które miały je przygotowywać do sukcesów na balach, przyjęciach i towarzyskich spotkaniach. Tak oto Michał Weyssenhoff (1715-1789), podkomorzy królewski podpisując 6 października 1786 r. kontrakt z nauczycielem muzyki Janem Cybulskim zastrzegł, że chce, aby ten uczył nie tylko jego synów, ale także dwie córki na klawicymbale oraz harfie, wyznaczając mu przy tym pięćdziesiąt czerwonych złotych pensji na rok $^{75}$. Dla wielu młodych arystokratek nauka muzyki nie była przyjemnością. Tak oto Zofia z Czartoryskich Zamoyska, wspominając lata młodości, zanotowała: Miałam dobrego metra od fortepianu, który mnie bił czasem, a ja bardzo płakałam, ale uczył dobrze $i$ byłabym dobra muzyczka, gdybym była zawczasu nie zaniedbała tego talentu ${ }^{76}$. Z kolei Henrietę z Działyńskich Błędowską uczył muzyki pan Gabel - rzadko zadowolony z jej postępów. Za nieprzykładanie się do lekcji młodziutką generałównę często karano ró$\mathrm{zgą}^{77}$.

Od najmłodszych lat każda szlachcianka uczyła się kroków oraz rytmu. Taniec odgrywał ważną rolę w wychowaniu młodzieży w czasach nowożytnych. Zofia z Czartoryskich Zamoyska uwielbiała zajęcia z metrem tańca. Te lekcje - wspominała po latach bawity mnie bardzo, a ponieważ dobrze tańczyłam $i$ bardzo mnie z tego chwalono, rozbudziło się we mnie zanadto wielkie umiłowanie tańca, jakby rzeczy ważnej ${ }^{78}$. Podobnie było z wieloma innymi magnackimi córkami. Wystrojone tańczyły z całą powagą,

${ }^{71}$ M. G. Zieliński, op. cit., s. 103-104.

72 F. Schulz, op. cit., t. II, s. 591-592.

73 Ibidem, s. 592.

74 Z. Janeczek, Ignacy Potocki (1750-1809), Katowice 1992, s. 39.

${ }^{75}$ Litewskie Państwowe Archiwum Historyczne w Wilnie, zespół 1505, sygn. 224, Kontrakt między Michałem Weyssenhoffem i nauczycielem muzyki Janem Cybulskim.

${ }^{76}$ Kufer Kasyldy, czyli wspomnienia z lat dziewczęcych..., s. 20.

77 H. z Działyńskich Błędowska, op. cit., s. 37.

${ }^{78}$ Kufer Kasyldy, czyli wspomnienia z lat dziewczęcych... s. 20. 
naśladując gesty, mimikę twarzy i ruchy osób dorosłych, szybko ucząc się sztuki występowania i błyszczenia. Podczas lekcji tańca uczyły się również wytwornego chodzenia i odpowiednich ukłonów ${ }^{79}$. Możni rodzice nie zaniedbywali nauki swoich córek nawet w podróżach. Katarzyna z Sosnowskich Platerowa, ekspisarzowa polna litewska podczas pobytu w Rzymie w latach 1785-1786 zatrudniła pana Pelli'ego - nauczyciela śpiewu i gry na klawesynie - by uczył jej córkę Cecylię $(1772-1858)^{80}$. Będąc w mieście, gdzie tak silnie rozkwitała szeroko rozumiana sztuka, zadbała także dla niej o nauczyciela rysunku ${ }^{81}$.

Guwernantki były ważnymi jednostkami w kręgach zamożnej szlachty czasów stanisławowskich. Każdy poważany rodzic zapewniał swojej córce odpowiednią do tamtejszych wymagań nauczycielkę i zarazem wychowawczynię. W większości pochodziły one z innych krajów, głównie z Francji, gdyż w Rzeczypospolitej Obojga Narodów brakowało wykształconych pań, które mogłyby poprowadzić naukę na odpowiednim poziomie. W rzeczywistości dopiero rodziły się idee kształcenia nauczycielek-krajanek i stawiano powolne kroki w realizowaniu tych zamierzeń. Tymczasem, guwernantki trafiały się dziewczynkom różne. Jedne były starsze, drugie umiały rozmawiać tylko w obcym języku, inne zupełnie zaniedbywały swoje podopieczne. Czasem trafiały się jednostki, które posiadały większe wykształcenie, niż zdolność porozumiewania się w innym języku. Arystokratki schyłku XVIII w. stawały się bardziej świadome swoich braków w wykształceniu i obserwowały zachodzące ówcześnie wokół nich zmiany. Zaczynały zwracać baczną uwagę na to, komu powierzają w opiekę swoje córki, choć też nie zawsze. Kiedy jednak guwernantka nie miała wiedzy ze wszystkich dziedzin życia, które mogłyby być przydatne młodej panience w przyszłości do pomocy zatrudniano dodatkowych nauczycieli. Zazwyczaj byli to mężczyźni, którzy uczyli rysunku, tańca, muzyki. Skupiano się zatem na rozwoju „talentów” dziewcząt oraz nabieraniu przez nie poloru. Tak wykształcone dziewczęta według współczesnych mogły wkraczać w towarzystwo i podbijać męskie serca, w poszukiwaniu dobrego i majętnego męża. W czasach stanisławowskich edukacja młodych arystokratek była bowiem powszechnie podporządkowana planom odpowiedniego wydania ich za mąż. Hubert Vautrin stwierdził wprost: Jak wszędzie, $i w$ Polsce panuje zdanie, że jedynym przeznaczeniem kobiet jest podobanie się ptci brzydkiej ${ }^{82}$.

\footnotetext{
${ }^{79}$ F. Schulz, op. cit., s. 592.

${ }^{80}$ K. z Sosnowskich Platerowa, Moja podróż do Włoch. Dziennik z lat 1785-1786, wstęp i oprac. M. E. Kowalczyk, przekład z j. franc. A. Pikor-Półtorak, Łomianki 2013, s. 135, 149.

${ }^{81}$ Ibidem, s. 139, 142.

${ }^{82}$ H. Vautrin, op. cit., s. 791.
} 


\section{Bibliografia}

\section{Źródła rękopiśmienne}

Archiwum Główne Akt Dawnych w Warszawie, Archiwum Zamoyskich, sygn. 76. Akta Konstancji z Czartoryskich Zamoyskiej.

Archiwum Narodowe w Krakowie, Oddział I na Wawelu, Archiwum Młynowskie Chodkiewiczów, sygn. 479, Kopiariusz listów Ludwiki Chodkiewiczowej oraz listy do różnych osób, 1768-1807.

Litewskie Państwowe Archiwum Historyczne w Wilnie, zespół 1505, sygn. 224, Kontrakt między Michałem Weyssenhoffem i nauczycielem muzyki Janem Cybulskim.

\section{Źródła drukowane}

Bernardin de Saint-Pierre J. H., Podróż po Polsce, w: Polska stanisławowska w oczach cudzoziemców, oprac. W. Zawadzki, t. I, Warszawa 1963.

Bieliński F., Sposób edukacji w XV listach opisany, które do Komisji Edukacji Narodowej od bezimiennego autora byly przesyłane R. P. 1775, w: Pisma i projekty pedagogiczne doby Komisji Edukacji Narodowej...

Czartoryski A., Drugi list Imć Pana Doświadczyńskiego do przyjaciela swego względem edukacyi córek w: S. Tync, Komisja Edukacji Narodowej: (pisma Komisji i o Komisji): wybór źródet, Wrocław 1954.

Dębicki L., Puławy (1762-1830). Monografia z życia towarzyskiego, politycznego i literackiego na podstawie archiwum ks. Czartoryskich w Krakowie, t. 4, Lwów 1888.

z Działyńskich Błędowska H., Pamiątka przeszłości. Wspomnienia z lat 1794-1832, oprac. K. Kostenicz i Z. Makowiecka, Warszawa 1960.

Fiszerowa W., Dzieje moje własne i osób postronnych. Wiązanka spraw poważnych, ciekawych i błahych, oprac. E. Raczyński, Londyn 1975.

„Gazeta Warszawska”, 1782, nr 5 + supl.

Kicka N., Pamiętniki, wstęp i przypisy J. Dutkiewicz, tekst oprac. T. Szafrański, Warszawa 1972.

Kołłątaj H., Wybór pism naukowych, oprac. K. Opałek, Warszawa 1953, s. 195-197.

Kufer Kasyldy, czyli wspomnienia z lat dziewczęcych. Wyboru z pamiętników XVIII-XIX w. dokonały D. Stępniewska i B. Walczyna, Warszawa 1974.

„Monitor” 1779, nr LIX.

Ojcowskie synom przestrogi. Instrukcje rodzicielskie (XVI-XVII w.), wstępem i objaśnieniami opatrzyły D. Żołądź-Strzelczyk i M.E. Kowalczyk, Wrocław 2017.

Przestrogi i nauki dla dzieci. Instrukcje rodzicielskie (XVIII w.), wstępem i objaśnieniami opatrzyły M.E. Kowalczyk, D. Żołądź-Strzelczyk, Wrocław 2017.

z Sosnowskich Platerowa K., Moja podróż do Włoch. Dziennik z lat 1785-1786, wstęp i oprac. M. E. Kowalczyk, przekład z j. franc. A. Pikor-Półtorak, Łomianki 2013

Popławski A., Nauka o prawie przyrodzonym krótko i jaśnie zebrana, [b.m.w.] 1771.

z Tyszkiewiczów Potocka-Wąsowiczowa A., Wspomnienia naocznego świadka, Warszawa 2010.

Prokopowicz A. M., Sposób nowy, najtatwiejszy, pisania i czytania razem dla panienek, z przypisami dla nauczycielek, Kraków 1790, Przedmowa do rodziców.

Rousseau J. J., Emil czyli o wychowaniu, wstęp i oprac. J. Legowicz, t. I, Wrocław 1995.

Schulz F., Podróże Inflantczyka z Rygi do Warszawy i po Polsce w latach 1791-1793, w: Polska stanisławowska w oczach cudzoziemców, oprac. W. Zawadzki, t. II, Warszawa 1963. 
Vautrin H., Obserwator w Polsce, w: Polska stanisławowska w oczach cudzoziemców, oprac. W. Zawadzki, t. I, Warszawa 1963.

Waga T., Historia książat i królów polskich krótko zebrana z niektórymi uwagami nad dziełami narodu dla oświecenia młodzi narodowej przez... do druku podana, Warszawa 1770.

Wyrwicz K., Geografia czasów teraźniejszych, albo opisanie naturalne i polityczne królestw, państw, stanów wszelkich, ich rządu, rzemiost, handlu, przemystu, przymiotów, obyczajów etc. ku pożytkowi narodowej młodzi wydana, t. I, Warszawa 1768.

Wyrwicz K., Geografia powszechna czasów teraźniejszych albo opisanie krótkie catego świata, ich położenia, granic, płodu ziemnego, skłonności obywatelów, handlu, obyczajów etc. etc. Z najświeższych wiadomości, krajopisarzów $i$ wędrowników zebrana ku pożytkowi młodzi narodowej na szkoty publiczne wydana, Warszawa 1770.

\section{Opracowania}

Aleksandrowicz A., Izabela Czartoryska. Polskość i europejskość, Lublin 1998.

Aleksandrowska E., Piramowicz Grzegorz Wincenty, w: Polski stownik biograficzny, t. 26, Wrocław-Warszawa-Kraków-Gdańsk-Łódź 1981, s. 529-536.

Aleksandrowska E., Popławski Antoni, w: Dawni pisarze polscy od początku piśmiennictwa do Młodej Polski, red. R. Loth, Warszawa 2002, s. 272-273.

Augustowska K., Karol Wyrwicz, w: Dziewięć wieków geografii polskiej. Wybitni geografowie polscy, pod red. B. Olszewicza, Warszawa 1967, s. 117-137.

Berdecka A., I. Turnau, Życie codzienne w Warszawie okresu Oświecenia, Warszawa 1969.

Bogucka M., Białogłowa w dawnej Polsce. Kobieta w społeczeństwie polskim XVI-XVIII wieku na tle porównawczym, Warszawa 1998.

Chamcówna M., Popławski Jacek, w: Polski stownik biograficzny, t. 26, Wrocław 1983, s. 602-603.

Chyra Z., Nauczyciele prywatni (1764-1807), w: Spoleczeństwo polskie XVIII i XIX wieku, red. J. Leskiewiczowa, t. VI, Państwowe Wydawnictwa Naukowe, Warszawa 1974, s. 7-41.

Dębicki L., Puławy (1762-1830). Monografia z życia towarzyskiego, politycznego i literackiego na podstawie archiwum ks. Czartoryskich w Krakowie, t. 1, Lwów 1887.

Godineau D., Kobieta, w: Człowiek Oświecenia, red. M. Vovelle, Warszawa 2001, s. 399-432.

Janeczek Z., Ignacy Potocki (1750-1809), Katowice 1992.

Kowalczyk M. E., Pamięć o tragicznie zmarlej księżniczce Teresie Czartoryskiej (1765-1780), w: Nie wszystek umrę. Pamięć o zmartych w kulturze staropolskiej, red. A. Jankowski, A. Klonder, Bydgoszcz 2015, s. 232-243.

Kowalczyk M. E., Wstęp, w: Apolonia Helena Massalska. Pamiętnik pensjonarki. Zapiski z czasów edukacji w Paryżu (1771-1779), wstęp i oprac. M. E. Kowalczyk, przekład z j. franc. A Pikor-Półtorak, Kraków 2012.

Kowalczyk M. E., Wstęp, w: K. z Sosnowskich Platerowa, Moja podróż do Włoch. Dziennik z lat 1785-1786, Łomianki 2013.

Leśnodorski B., Kołtątaj Hugo, w: Polski słownik biograficzny, t. 13, Wrocław-Warszawa-Kraków 1967-1968, s. 335-346.

Linde S. B., Stownik języka polskiego, t. 1, cz. 2, Warszawa 1808.

Ludwisiak M., Postać Jana Jakuba Rousseau i jego wpływ na współczesnych, „Acta Universitatis Lodziensis. Folia Historrica" T. 81, 2007, s. 87-108.

Majewska-Maszkowska B., Mecenat artystyczny Izabelli z Czartoryskiej Lubomirskiej (1736-1816), Wrocław 1976. 
Mitera-Dobrowolska M., Zainteresowanie Komisji Edukacji Narodowej sprawa wychowania dziewczat, w: Ł. Kurdybacha, M. Mitera-Dobrowolska, Komisja Edukacji Narodowej, Warszawa 1973 , s. $173-189$.

Mrozowska K., Rozwój koncepcji pedagogicznych w XVIII w., w: Pisma i projekty pedagogiczne doby Komisji Edukacji Narodowej, Wrocław-Warszawa-Kraków-Gdańsk 1973, s. V-LXX.

Podgórska E., Sprawa wychowania kobiet w znaczniejszych czasopismach polskich drugiej połowy XVIII wieku, „Rozprawy z Dziejów Oświaty” 1961, t. IV, s. 19-33.

Słowikowski T., Pijarskie podręczniki do nauczania historii w Polsce w XVIII wieku, „Nasza Przeszłość", t. 54, 1980, s. 181-299.

Snopek J., Oświecenie. Szkic do portretu epoki, Warszawa 1999.

Stetkiewiczówna W., System wychowania kobiet wedtug KEN, „Przegląd Pedagogiczny” 1924, z. IV, s. 216-243.

Szybiak I., O rodzicielskich zaletach $i$ wadach $w$ oświeceniowej polskiej publicystyce edukacyjnej. w: Nauczanie domowe dzieci polskich od XVIII do XX wieku. Zbiór studiów, red. K. Jakubiak, A. Winiarz, Bydgoszcz 2004, s. 35 - 45.

Waniczkówna H., Czartoryski Adam Kazimierz, w: Polski słownik biograficzny, t. 4, Kraków 1938, s. $249-257$.

Wolff A. i Budka W., Bieliński Franciszek, w: Polski słownik biograficzny, t. 2, Kraków 1936, s. $50-51$.

Wrońska K., Uwagi o recepcji twórczości pedagogicznej Johna Locke'a w Polsce z perspektywy pedagogiki filozoficznej, w: Filozofia wychowania w Europie Środkowej w kontekście uwarunkowań historycznych, społecznych, politycznych i filozoficznych, red. S. Sztobryn, K. Kamiński, M. Wasilewski, Łódź 2015, s. 15-35.

Wrońska K., Johna Locke'a koncepcja wychowania - zapowiedź oświeconych przemian w myśli pedagogicznej, https://ruj.uj.edu.pl/xmlui/bitstream/handle/item/22260/wronska_johna_locke\% 27a_koncepcja_wychowania.pdf?sequence=1\&isAllowed=y [dostęp: 15.06.2018].

Zielińska Z., Potocki Roman Ignacy Franciszek, w: Polski stownik biograficzny, t. 28, WrocławWarszawa-Kraków-Gdańsk-Łódź 1984-1985, s. 1-17.

Zieliński M.G., Rola cudzoziemek $w$ procesie edukacji młodzieży $w$ okresie stanisławowskim (1764-1795), w: Rola i miejsce kobiet w edukacja i kulturze polskiej, t. 1, red. W. Jamrożek i D. Żołądź-Strzelczyk, Poznań 1998, s. 102-108.

Żołądź D., Ideały edukacyjne doby staropolskiej. Stanowe modele i potrzeby edukacyjne szesnastego i siedemnastego wieku, Warszawa-Poznań 1990.

Żołądź-Strzelczyk D., „Jako rządzić maja rodzice córki swe”. Poglądy na wychowanie kobiet w XVI-XVIII w., w: Rola i miejsce kobiet $w$ edukacji i kulturze polskiej, red. W. Jamrożek i D. Żołądź-Strzelczyk, t. 1, Poznań 1998, s. 53-63.

Żołądź-Strzelczyk D., Antoniego Maksymiliana Prokopowicza Sposób nowy najłatwiejszy pisania i czytania razem dla panienek z przypisami dla nauczycielek - pierwszy polski podręcznik edukacji elementarnej dla dziewcząt, „Kwartalnik Historii Kultury Materialnej” 2014, R. 62, nr 4, s. 553-565. 